Research Journal of Applied Sciences 5 (2): 47-53, 2010

ISSN: $1815-932 \mathrm{X}$

(C) Medwell Journals, 2010

\title{
Modeling the Impacts of Ringlet Reservoir on Downstream Hydraulic Capacity of Bertam River Using XPSWMM in Cameron Highlands, Malaysia
}

\author{
${ }^{1}$ Othman Jaafar, ${ }^{2}$ Mohd. Ekhwan Toriman, ${ }^{2}$ S.A. Sharifah Mastura, ${ }^{3}$ Muhamad Barzani Gazim, \\ ${ }^{3} \mathrm{Pan}$ Ia Lun, ${ }^{4} \mathrm{Pauzi}$ Abdullah, ${ }^{2}$ Mohd Khairul Amri Kamarudin and ${ }^{2}$ Nor Azlina Abdul Aziz \\ ${ }^{1}$ Department of Civil Engineering, Faculty of Civil Engineering, \\ University Kebangsaan Malaysia, 43600 Bangi Selangor, Malaysia \\ ${ }^{2}$ School of Social Development and Environmental Studies (FSSK), \\ ${ }^{3}$ School of Environment Natural Resource Sciences (FST), \\ ${ }^{4}$ School of Chemical Sciences and Food Technology (FST), \\ University Kebangsaan Malaysia, 43600 Bangi Selangor, Malaysia
}

\begin{abstract}
Bertam river (Sg. Bertam) is one of the main rivers in Cameron Highlands, Pahang. The downstream river has changed as a result of water storage and regulation in the Ringlet reservoir. The changes include a reduction in discharge volume and water level downstream the reservoir. This study deals with the impacts of Ringlet reservoir to downstream hydraulic capacity of Bertam river. In order to study the impact, the hydraulic simulation of river was carried out using the 1-D hydrodynamic software of XP-SWMM. The software is capable to model the difference of water level before and after the reservoir as well as to estimate the fluctuation of water level along the river. Eighteen river cross stations were surveyed on August 2008 along the Sg. Bertam. The distance between each cross section was approximately $\mathrm{I} \mathrm{km}$. This study was found that the reservoir had given significant impacts to the downstream hydraulic capacity in Bertam river. This includes decreasing in river discharge, reduction in bankfull width and the characteristics of the downstream flood scenario.
\end{abstract}

Key words: Sg. Bertam, river discharge, hydrodynamic model, XP-SWMM, reservoir, flood

\section{INTRODUCTION}

The introduction of the digital computer into hydrology during the 1960's and 1970's allowed complex water problems to be simulated as complete systems for the first time. Large computer models can now be used to match historical data and help answer difficult hydrologic questions (Toriman et al., 2009a, b; Beven, 2001). The XPSWMM comprehensively models the hydrologic and hydraulic components of most storm water management systems (Philip et al., 2008). It includes modeling capabilities for continuous simulation, numerous hydrograph generation methods, mixtures of open channel and closed conduits, looped networks, storage nodes such as ponds and multiple outfall.

Surface water resources have played an important function throughout the history in the development of human civilization. About one third of the drinking water requirement of the world is obtained from surface sources like rivers, canals and lakes (Das and Acharya, 2003). According to Krishnayya (2003), watersheds by nature are dynamic systems and in a constant state of change. But in addition to natural watershed changes, the response of a watershed can change drastically due to changes associated with human activities. Around $70 \%$ of the world's rivers are intercepted by large reservoirs. A notable threat to the sustainability of reservoirs is sedimentation. It is estimated that $1 \%$ of the existing storage volume in the world is lost each year. The theoretical sediment trapping efficiency in these reservoirs are high, half of the reservoirs showing a local sediment trapping efficiency of $80 \%$ or more (Vörösmarty et al., 2003).

According to the research by William (2006) and Jessica et al. (2005), the impoundment of river regulates discharge downstream, flow regime, sediment transport and the hydraulic gradient downstream. The ringlet reservoir is a man-made lake created upstream of the

Corresponding Author: Othman Jaafar, Department of Civil Engineering, Faculty of Civil Engineering,

University Kebangsaan Malaysia, 43600 Bangi Selangor, Malaysia 
concrete dam on Bertam river and forms an integral part of the Cameron Highlands Hydroelectric Scheme. The dam is known as the Sultan Abu Bakar Dam (Empangan Sultan Abu Bakar), consists of a mass concrete gravity section on the left bank and a rockfill section on the right bank. It impounds the water of Bertam river and its tributaries and those of Sg. Telom, Sg. Plau'ur, Sg. Kodol and Sg. Kial which have been diverted from the Telom catchment through the Telom tunnel into the Bertam catchment. The reservoir was impounded in early 1963 and is located about $570 \mathrm{~m}$ above the Jor Power Station.

It is about $3 \mathrm{~km}$ in length with varying width and has a surface area of approximately 60 ha. The designed gross storage of the reservoir is about 6.7 million $\mathrm{cm}^{3}$ of which 4.7 million $\mathrm{cm}^{3}$ is usable storage (Choy and Hamzah, 2001). There were incidences of water qualities and aquatic lives in the Ringlet Reservoir being badly affected in the past when excessive sediment/silt content and high chemical content (e.g., pesticides and fertilizers) resulted in dying of fish and wide spread of water hyacinth. According to Gasim et al. (2009), the land uses for agricultural and urban area development have increased since 1995-2003, that is from 5125-5671 ha for agriculture and 593-830 ha for urbanization, respectively.

Meanwhile, according to Choy and Hamzah (2001), extensive deforestation and indiscriminate earth bulldozing in the Cameron Highlands area for agricultural and housing development has resulted in widespread soil erosion over the land surface. It leads to sedimentation of the streams and the Ringlet reservoir from which water is drawn to the power station. This study limits its exploration to the downstream effects on hydraulic and hydrology of the Bertam River through the study of capacity of river by using XP-SWMM modeling software.

Study area: The Cameron Highlands catchment is situated on the Main Range of the Peninsular Malaysia. The average elevation of the catchment area is approximately $1829 \mathrm{~m}$ above sea level. The area of Cameron Highlands is about 71, 218 ha (Gasim et al., 2009). Cameron Highlands lies at $4^{\circ} 19^{\prime}-4^{\circ} 37^{\prime} \mathrm{N}$ and $101^{\circ} 21^{\prime}-101^{\circ} 301^{\prime} \mathrm{E}$ is a mountainous region located in Pahang state, Malaysia. Cameron Highlands is bordered by Lipis district on the south-east, Kelantan on the north and Perak on the west.

The temperatures are not higher than $25^{\circ} \mathrm{C}$. The average annual rainfall is $2660 \mathrm{~mm}$ with peaks in the months of May and October. Gunung Brinchang is the highest point of Cameron Highlands with 2031 m (6664 feet) above sea level (James, 1968). Bertam River is one of the three main rivers (Bertam River, Telom River and Lemoi River) in Cameron Highlands which are the main water resource for the domestic uses. The river supplied the water for agricultural, irrigation and electricity generation. Sungai Bertam is the most important river flowing into the TNB Ringlet Reservoir where the Dam Sultan Abu Bakar was commissioned in 1965 (Barrow et al., 2005). Currently, Sg. Bertam was contaminated and heavily silted, especially after passing through the settlement and agricultural areas (Gasim et al., 2009; Barrow et al., 2008).

\section{MATERIALS AND METHODS}

Global Positioning System (GPS) was used to determine the actual coordinate of the river survey (Table1). About 18 river cross sections were selected. Nine stations were located before reservoir and the other nine stations are located downstream the reservoir. The distance between each cross section areas are approximately $1 \mathrm{~km}$. The field survey was carried out on the 9 August 2008 (sunny day). During the survey, the observed discharge (Q) was also measured involved measuring the depth and width of the river using Eq. 1.

Table 1: Location and brief description of each station at Sg. Bertam, Cameron Highlands

\begin{tabular}{|c|c|c|c|c|c|c|c|}
\hline Stn & Location/river & Distance (km) & Elevation (m) & Stn & Location/river & Distance (km) & Elevation (m) \\
\hline 1 & 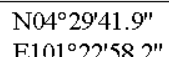 & 1 & 1509 & 10 & $\begin{array}{l}\mathrm{N} 04^{\circ} 25^{\prime} 1.9^{\prime \prime} \\
\mathrm{E} 101^{\circ} 23^{\prime} 51\end{array}$ & 1 & 1030 \\
\hline 2 & 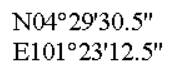 & 1 & 1500 & 11 & $\begin{array}{l}\text { N04 }{ }^{\circ} 24^{\prime} 50.3^{\prime \prime} \\
\mathrm{E} 101^{\circ} 24^{\prime} 8.6^{\prime \prime}\end{array}$ & 1 & 1025 \\
\hline 3 & $\begin{array}{l}\text { N04 } 29^{\prime} 14.2^{\prime \prime} \\
\text { E101 } 23^{\circ} 8.3^{\prime \prime}\end{array}$ & 1 & 1475 & 12 & $\begin{array}{l}\text { N04 } 24^{\prime} 45.1^{\prime \prime} \\
\text { E101 } 24^{\prime} 39^{\prime \prime}\end{array}$ & 1 & 1014 \\
\hline 4 & 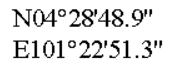 & 1 & 1456 & 13 & $\begin{array}{l}\mathrm{N} 04^{\circ} 24^{\prime} 33.5^{\prime \prime} \\
\mathrm{E} 101^{\circ} 25^{\prime} 0.5^{\prime \prime}\end{array}$ & 1 & 1002 \\
\hline 5 & 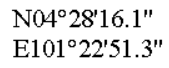 & 1 & 1426 & 14 & $\begin{array}{l}\mathrm{N} 04^{\circ} 24^{\prime} 26.3^{\prime \prime} \\
\mathrm{E} 101^{\circ} 25^{\prime} 25.6^{\prime \prime}\end{array}$ & 1 & 983 \\
\hline 6 & 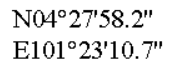 & 1 & 1423 & 15 & $\begin{array}{l}\mathrm{N} 04^{\circ} 24^{\prime} 26.8^{\prime \prime} \\
\mathrm{E} 101^{\circ} 25^{\prime} 53.4^{\prime \prime}\end{array}$ & 1 & 964 \\
\hline 7 & 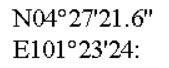 & 1 & 1139 & 16 & $\begin{array}{l}\mathrm{N} 04^{\circ} 24^{\prime} 25.6^{\prime \prime} \\
\mathrm{E} 101^{\circ} 26^{\prime} 18^{\prime \prime}\end{array}$ & 1 & 954 \\
\hline 8 & $\begin{array}{l}\text { N04 } 26^{\circ} 58^{\prime \prime} \\
\text { E101 } 233^{\circ} 27.1^{\prime \prime}\end{array}$ & 1 & 1110 & 17 & $\begin{array}{l}\text { N04ㅇ2 } 24^{\prime} 31.9^{\prime \prime} \\
\text { E101 } 26^{\prime} 53^{\prime \prime}\end{array}$ & 1 & 925 \\
\hline 9 & $\begin{array}{l}\text { N04 } 20^{\circ} 34.3^{\prime \prime} \\
\mathrm{E}^{\prime} 01^{\circ} 23^{\prime} 17.8^{\prime \prime}\end{array}$ & 1 & 1076 & 18 & $\begin{array}{l}\mathrm{N} 4^{\circ} 24^{\prime} 41.5^{\prime \prime} \\
\mathrm{E} 101^{\circ} 27^{\prime} 23.6^{\prime \prime}\end{array}$ & 1 & 907 \\
\hline
\end{tabular}




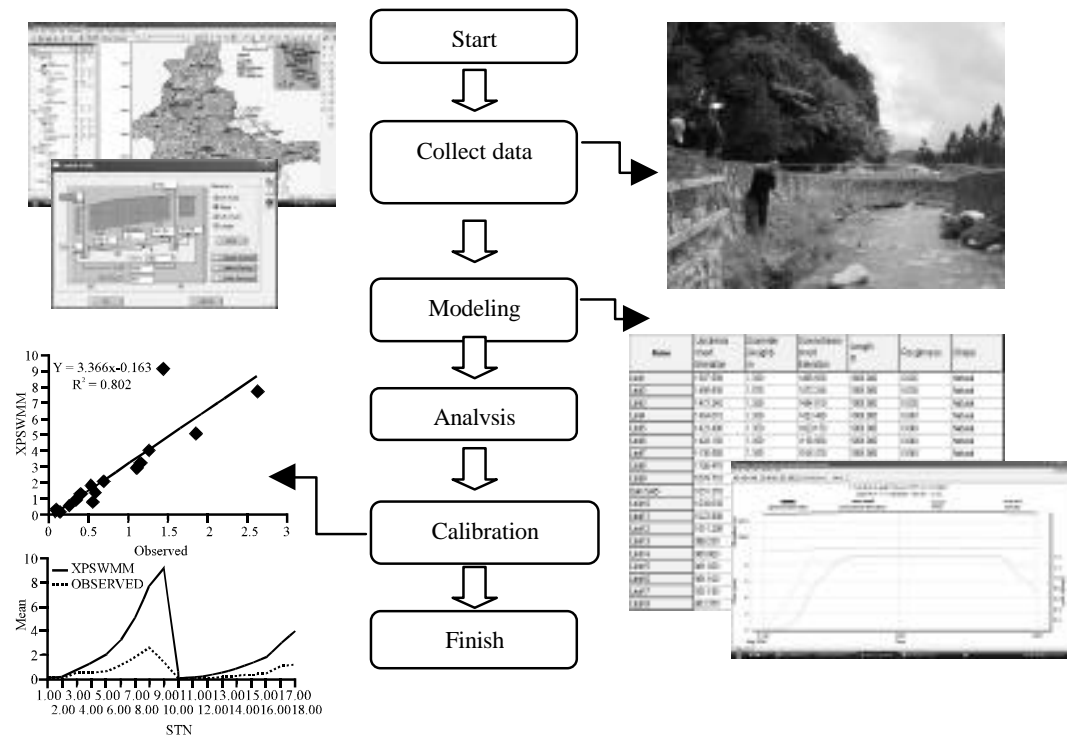

Fig. 1: The process of modeling data

$$
\text { Flow } \begin{aligned}
\left(\mathrm{m}^{3} \mathrm{sec}^{-1}\right) & =\sum(\text { Depth, } \mathrm{d} \times \text { Width, } \mathrm{l}) \times \text { Velocity of flow } \\
= & \text { Area }\left(\mathrm{m}^{2}\right) \times \text { Velocity of flow }\left(\mathrm{m} \mathrm{sec}^{-1}\right)
\end{aligned}
$$

The hydrodynamic model used in this study is XP-SWMM, a 1-D dimension which models the hydrologic and hydraulic components of most storm water management systems; based on cross-sections data obtained from the study area. XP-SWMM uses a node-link concept to represent the drainage system, whereby links represented hydraulic elements of flow in the system and the model offered many different types of conduits for simulation such as sewer pipes, channel reaches or culvert and nodes represented as pond or lake, junctions, outfalls or other physical transition points along the links (Toriman et al., 2009a, b).

To build a river model using XP-SWMM modeling software, some of the data are required in order to run the simulation. This includes river hydraulic information such as river cross-section, river depth and width. The river was modeled as conduits in combination with weir which added by using Multi link. Additional feature data including virtual or dummy features were also added directly into XP-SWMM (Toriman et al., 2009a, b). Overall, this modeling process can be simplified in Fig. 1.

\section{RESULTS AND DISCUSSION}

The Bertam River was modeled in the XP-SWMM using the link-node concept. The XP table of model was comprised of 20 nodes where 18 nodes represented as station and one node was represented as Node D which
Table 2: XP tables showing the nodes input data

\begin{tabular}{lcc}
\hline Name & Invert elevation (m) & Ground elevation (Spill crest) (m) \\
\hline St1 & 1507.590 & 1509.000 \\
St2 & 1498.930 & 1500.280 \\
St3 & 1472.240 & 1475.000 \\
St4 & 1454.010 & 1456.000 \\
St5 & 1423.490 & 1426.000 \\
St6 & 1420.150 & 1423.000 \\
St7 & 1136.580 & 1139.000 \\
St8 & 1106.470 & 1110.000 \\
St9 & 1074.710 & 1076.060 \\
Node D & 1051.370 & 1053.000 \\
St10 & 1028.030 & 1030.000 \\
St11 & 1022.900 & 1025.000 \\
St12 & 1011.200 & 1014.000 \\
St13 & 998.230 & 1002.000 \\
St14 & 980.000 & 983.000 \\
St15 & 961.030 & 964.000 \\
St16 & 951.100 & 954.000 \\
St17 & 921.190 & 925.000 \\
St18 & 903.370 & 907.000 \\
St19 & 900.000 & 904.000 \\
\hline
\end{tabular}

represented as outfall from the reservoir as well (Table 2) and one dummy was added as St 19 and assigned as free outfall. The link here represented as open and natural conduit. This study comprised of 19 links and one link was represented as Sultan Abu Bakar Dam (Dam SAB), which also represented as a reservoir (Table 3). In this study, the 1-D dynamic plan plotting was selected to show the results (Fig. 2). The model had showed the maximum level of river water on the profile during the simulation and the flow discharges before and after the reservoir.

The discharge of each station was relatively low. According to the observed data, the discharge ranged from $0.079-2.619 \mathrm{~m}^{3} \mathrm{sec}^{-1}$ with average value of $0.739 \mathrm{~m}^{3} \mathrm{sec}^{-1}$. The average of discharge of nine stations 
Res. J. Applied Sci., 5 (2): 47-53, 2010

Table 3: XP tables showing the links input data

\begin{tabular}{|c|c|c|c|c|c|c|}
\hline Name & $\begin{array}{l}\text { Upstream invert } \\
\text { elevation }\end{array}$ & $\begin{array}{c}\text { Diameter } \\
\text { (hieght) (m) }\end{array}$ & $\begin{array}{c}\text { Downstream } \\
\text { invert elevation }\end{array}$ & Lenght (m) & Roughness & Shape \\
\hline Link1 & 1507.590 & 1.350 & 1498.930 & 1000.000 & 0.025 & Natural \\
\hline Link2 & 1498.930 & 1.070 & 1472.240 & 1000.000 & 0.030 & Natural \\
\hline Link3 & 1472.240 & 1.350 & 1454.010 & 1000.000 & 0.030 & Natural \\
\hline Link4 & 1454.010 & 1.350 & 1423.490 & 1000.000 & 0.040 & Natural \\
\hline Link5 & 1423.490 & 1.350 & 1420.150 & 1000.000 & 0.040 & Natural \\
\hline Link6 & 1420.150 & 1.350 & 1136.580 & 1000.000 & 0.040 & Natural \\
\hline Link7 & 1136.580 & 1.350 & 1106.470 & 1000.000 & 0.040 & Natural \\
\hline Link8 & 1106.470 & 1.350 & 1074.710 & 1000.000 & 0.040 & Natural \\
\hline Link9 & 1074.710 & 1.350 & 1051.370 & 2000.000 & 0.014 & Natural \\
\hline Dam SAB & 1051.370 & 1.350 & 1028.900 & 1000.000 & 0.014 & Power Fn \\
\hline Link10 & 1028.030 & 1.350 & 1022.900 & 1000.000 & 0.040 & Natural \\
\hline Link11 & 1022.900 & 1.350 & 1011.200 & 1000.000 & 0.040 & Natural \\
\hline Link12 & 1011.200 & 1.350 & 998.230 & 1000.000 & 0.040 & Natural \\
\hline Link13 & 998.230 & 1.350 & 980.000 & 1000.000 & 0.040 & Natural \\
\hline Link14 & 980.000 & 1.350 & 961.030 & 1000.000 & 0.040 & Natural \\
\hline Link15 & 961.030 & 1.350 & 951.100 & 1000.000 & 0.040 & Natural \\
\hline Link16 & 951.100 & 1.350 & 921.190 & 1000.000 & 0.040 & Natural \\
\hline Link17 & 921.190 & 1.350 & 903.370 & 1000.000 & 0.040 & Natural \\
\hline Link18 & 903.370 & 1.350 & 900.000 & 1000.000 & 0.040 & Natural \\
\hline
\end{tabular}

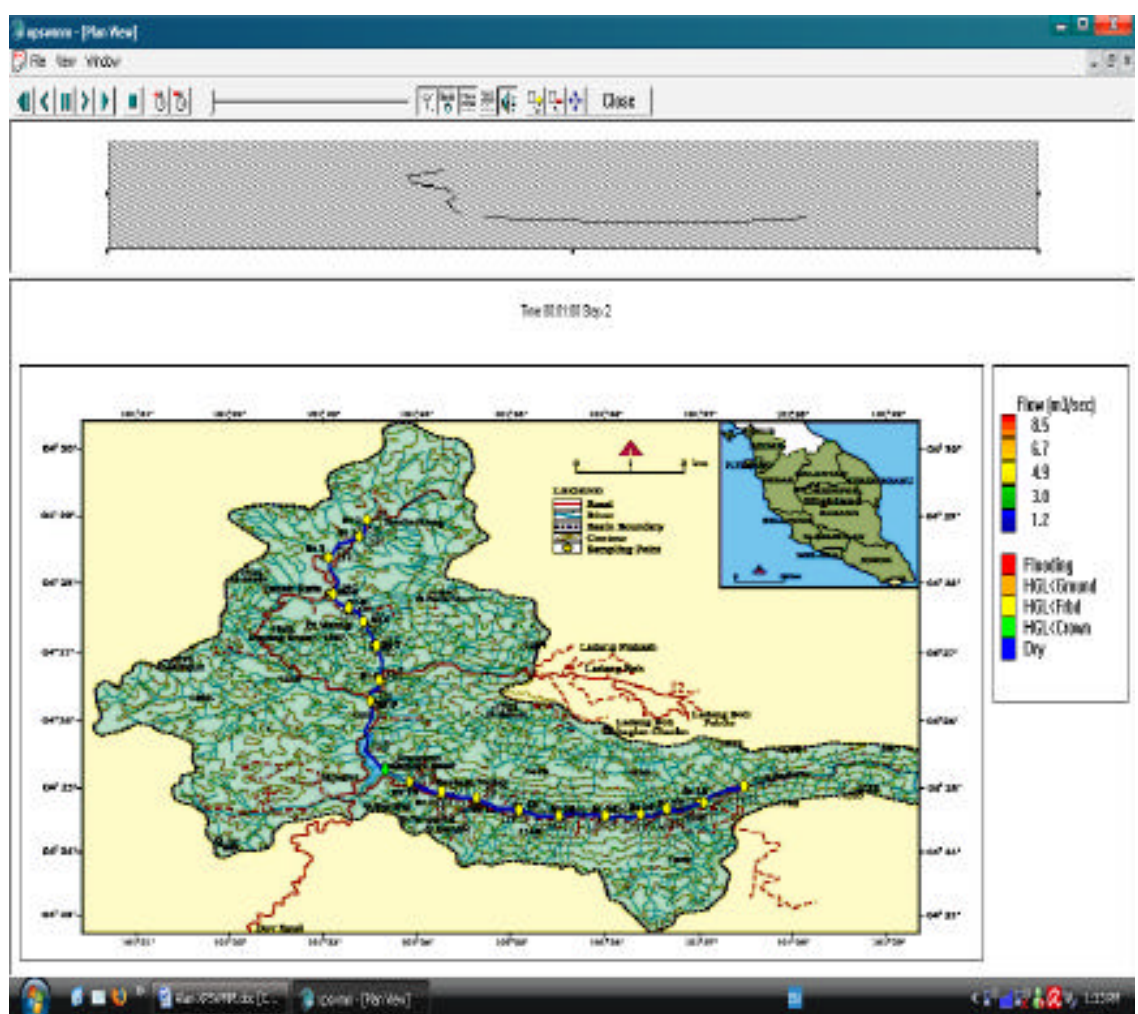

Fig. 2: The 1-D dynamic plan plotting for Bertam river network before the animation

before the reservoir was $1.013 \mathrm{~m}^{3} \mathrm{sec}^{-1}$ and the average discharge of nine stations after the reservoir was $0.464 \mathrm{~m}^{3} \mathrm{sec}^{-1}$. Station 8 had the highest discharge of $2.619 \mathrm{~m}^{3} \mathrm{sec}^{-1}$ and station 10 had the lowest discharge of $0.079 \mathrm{~m}^{3} \mathrm{sec}^{-1}$.

The model of XP-SWMM showed the discharge ranged from $0.079-9.118 \mathrm{~m}^{3} \mathrm{sec}^{-1}$. Station 9 had the highest discharge with $9.118 \mathrm{~m}^{3} \mathrm{sec}^{-1}$ which was located before the reservoir, while Station 10 had the lowest discharge with $0.079 \mathrm{~m}^{3} \mathrm{sec}^{-1}$ which located after the reservoir. The model showed the average of first nine stations before the reservoir was $3.3 \mathrm{~m}^{3} \mathrm{sec}^{-1}$ and the average of the rest stations after the reservoir was $1.35 \mathrm{~m}^{3} \mathrm{sec}^{-1}$. All together, the average of eighteen stations is $2.32 \mathrm{~m}^{3} \mathrm{sec}^{-1}$ (Fig. 3). The model also capable to model the flood scenario in the study area. Five 


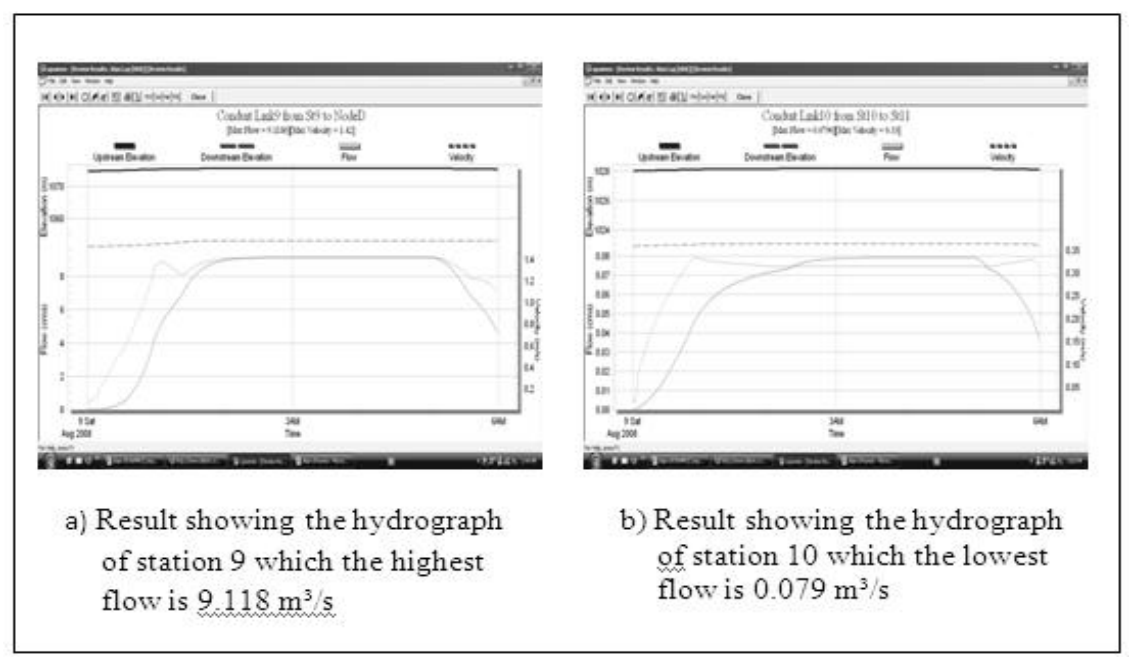

Fig. 3: Result showed the maximum and minimum flow of station

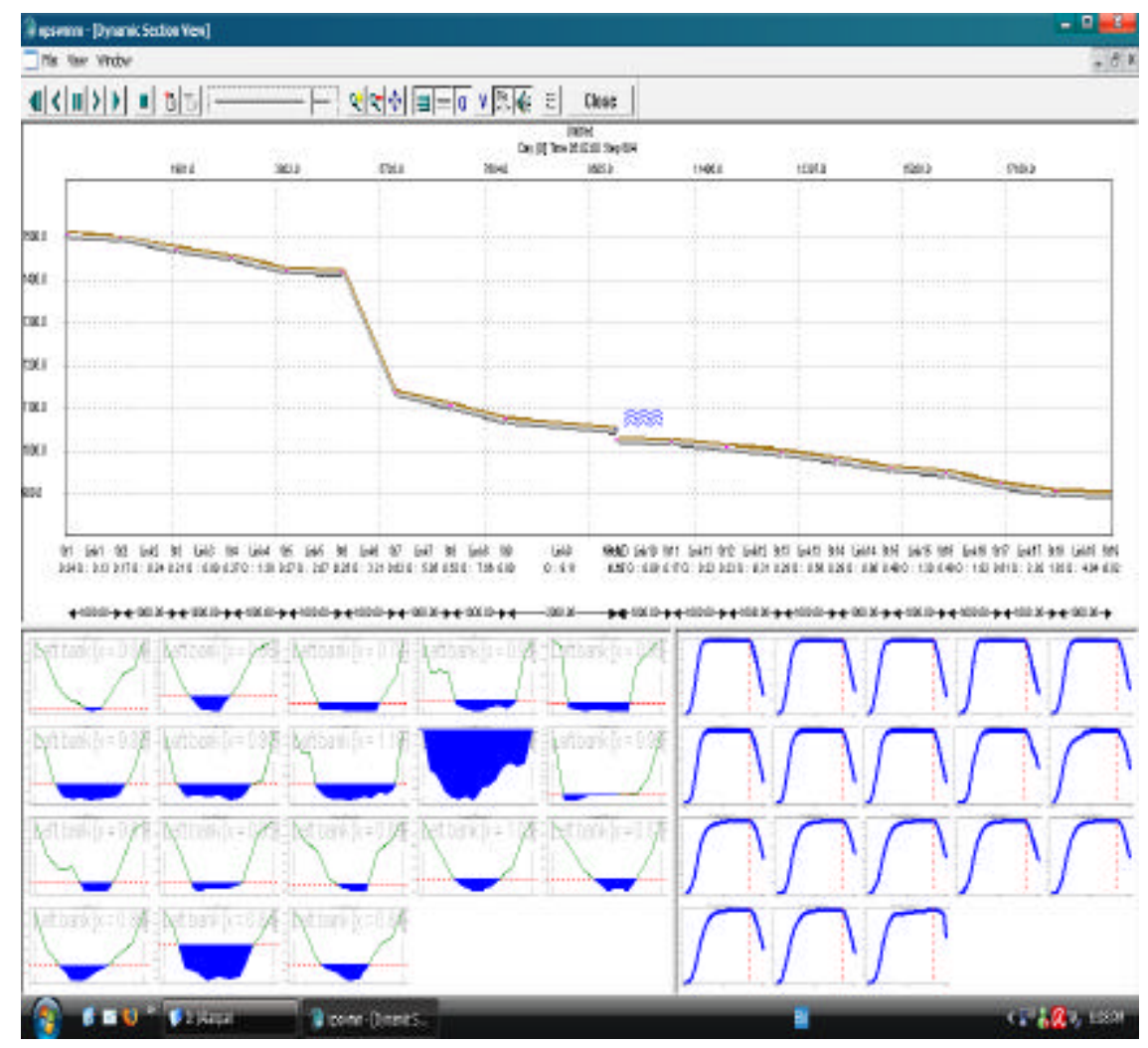

Fig. 4: Representation of the profile, cross sections and hydrographs

symbols were used as indicator of water level and river discharge at the study area namely flooding, ground level, freeboard, crown and invert level. In this study, flooding was interpreted as the distance when High Ground Level (HGL) is equal or exceeds the spill crest value. Ground level is the distance when the HGL is between spill crest and invert. Freeboard is the distance from a user defined safety elevation to the spill crest. Crown is the distance when HGL between highest crown value and invert. Dry is the distance when HGL is equal to invert. The animation 
revealed that link-9 was at flooding level which was overflowing the maximum river capacity, it was denoted that the station was nearest to the reservoir and its discharge was the highest compared to other stations. The animation showed that after the reservoir, namely link 10-16 were almost dry or only had very little river discharge which were below the HGL level and most of the time it only eligible to define as dry level.

The dynamic section view can be played on a multipanel view presenting a profile, cross sections and hydrographs (Fig. 4). The dynamic section view in the simulation is a construction of the contiguous segment of the Bertam River network. Profiles for contiguous segment of the Bertam River network were selected for animation. The profile displayed the water levels and high ground level over the course of simulation. The red line showed on the profile was the maximum depth water reaches during the simulation. From the simulation, it can be observed that node-D was expected to flooding at the end of the simulation with the flow discharge of $9.118 \mathrm{~m}^{3}$ $\mathrm{sec}^{-1}$ and velocity at $1.42 \mathrm{~m} \mathrm{sec}^{-1}$. The observed and simulation data were calibrated using Pearson Correlation. Figure 5 showed the trends of the flows from both data were quite similar. Meanwhile, the result illustrated in Fig. 6, indicated that the model estimated was typically higher compared with observed data. The reason was that XP-SWMM simulation had done the calibration using its model's standard and calculation. In Table 4, the results showed that $\mathrm{r}$ between observed data and simulation data was 0.896 with $\mathrm{p}=0.000$.

The simulation clearly showed that there was a decrease of discharge at the downstream of Bertam River. As a result, this can caused problems related to physical characteristic and hydrologic behavior of the river. Since Cameron Highlands is a mountainous region and the stream flow and its water level were much more affected by the gravitational force which resulted the lower flow of river. The impoundment of river would change the natural stream behavior (William, 2006; Jessica et al., 2005). In this case, the reservoir had further lower the discharge of downstream of Bertam River and had caused a small discharge which unable to flush the sediments away where it triggered from the surrounding area by the geomorphic processes and it accumulated and remained on the river bed and caused the siltation of the river. According to Jakob and Jordan (2001), debris flow has been identified as one of the most common and damaging geomorphic processes in mountainous region.

Many land use activities occur nearly simultaneously in a region, producing greater cumulative effects than would result from any single activity. Due to river siltation and small discharge, therefore the river was

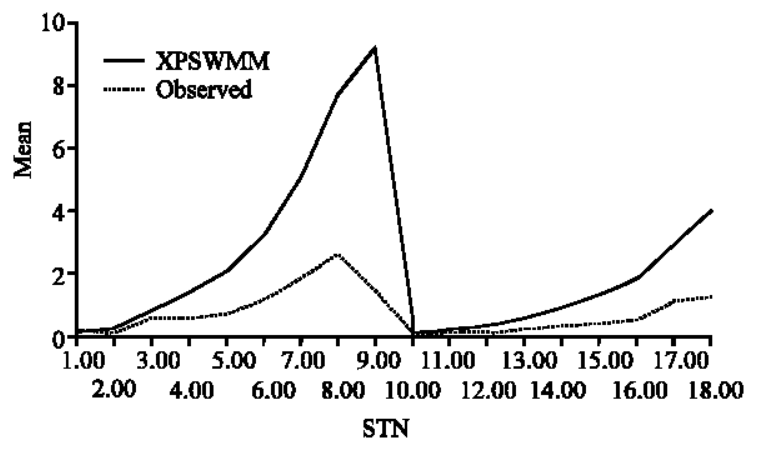

Fig. 5: Calibration of observed and XPSWMM simulation data

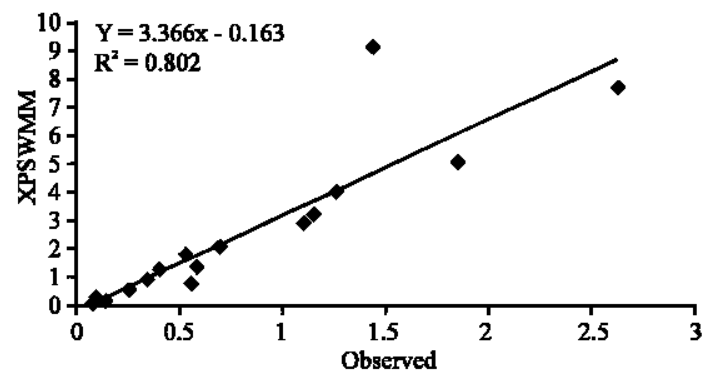

Fig. 6: Graph showing $r$ square of observed and XPSWMM discharge simulation data

Table 4: Correlation between observed and simulation data

\begin{tabular}{lll}
\hline Variables & Observed & XPSWMM \\
\hline Observed & & \\
Pearson correlation & 1 & $0.896\left(^{* *}\right)$ \\
Sig. (2-tailed) & - & 0.000 \\
N & 18 & 18 \\
XPSWMM & & \\
Pearson correlation & $0.896\left(^{* * *}\right)$ & 1 \\
Sig. (2-tailed) & 0.000 & - \\
N & 18 & 18 \\
\hline
\end{tabular}

** Correlation is significant at the 0.01 level (2-tailed)

become yellowish in color and the self-purification capacity of rivers has decreased. The trapping of sediment at upstream river by reservoir or dam would caused an instability of the river. Studied by Allan (2006) indicates that if upstream and downstream were connected, sediment might transported from mountainous headwaters exerts an important control on downstream channel stability and increases or decreases in sediment supply can destabilize downstream channel segments. The disconnection of upstream and downstream had caused the interruption of upstream-downstream movement of water, sediment, nutrients and organisms by dam or reservoir. These would lead to the changes of the ecosystem and biodiversity of the aquatic organism of downstream river. Another problem might include the occurring of new species of aquatic organism which might adapt to the lower flow river environment. The 
distribution of the aquatic organism might have a greater difference due to the disconnection of the upstream and downstream river.

In order to fill in the reservoir, inflow must exceed outflow (Philip et al., 2008). If sedimentation was occurred at the reservoir and it would caused the water retaining capacity of reservoir to decrease and it would pose a danger to the downstream area if overflow was occurred. According to Toriman et al. (2009b), any sudden flow of water through the rivers and tributaries during heavy rain would pose a danger to residents, as the valves of the Sultan Abu Bakar dam would have to be opened to let the water out and this would cause a disaster to over 3,000 residents living in the Bertam Valley.

\section{CONCLUSION}

It is ideal to use XP-SWMM modeling software to model the Bertam River in order to understand the hydraulic and hydrological impacts of Ringlet Reservoir to the downstream river. The model clearly showed that, there was a decreased of discharge of downstream Bertam River because of the regulation of the reservoir. It had caused some problems related to physical characteristics and hydrologic behavior of the river such as reduction in the discharge volume at downstream site as well as siltation problem. The study found that the impoundment of river as reservoir not only caused the siltation to the reservoir itself but it also caused the siltation to the river reach after the reservoir. The disconnection of upstream and downstream had caused the interruption of upstream-downstream movement of water, sediment, nutrients and organisms by the Ringlet reservoir.

\section{ACKNOWLEDGEMENT}

This study was conducted and supported by the GUP fund, University Kebangsaan Malaysia (UKM-GUPASPL-07-06-002) and UKM-GUP-ASPL-07-05-141. The researchers thankful to the Centre for Research Innovation and Management (CRIM), University Kebangsaan Malaysia for funding the research and providing computer laboratory analysis.

\section{REFERENCES}

Allan, W., 2006. Human impacts to mountain streams. Geomorphology, 79: 217-248.

Barrow, C.J., J. Clifton, N.W. Chan and Y.L. Tan, 2005. Sustainable development in Cameron highlands, Malaysia. Malaysian J. Environ. Manage., 6: 41-57.

Barrow, C.J., N.W. Chan and T. Masron, 2008. Evolving more sustainable sustainable agriculture in the Cameron Highlands, Malaysia. Int. J. Agric. Resour. Governance Ecol., 7: 450-468.
Beven, K., 2001. The future of distributed models: Model calibration and uncertainty prediction. Hydrol. Earth Syst. Sci., 5: 1-12.

Choy, F.K. and F.B. Hamzah, 2001. Cameron highlands hydroelectric scheme: Landuse change-impacts and issues. Proceedings 4th International Conference on Hydropower, June 20-22, Bergen, Norway, pp: 215-221.

Das, J. and B.C. Acharya, 2003. Hydrology and assessment of lotic water quality in Cuttack city, India. Water Air Soil Pollut., 150: 163-175.

Gasim, M.B., I. Sahid, M.E. Toriman, J.J. Pereira, M. Mokhtar and M.P. Abdullah, 2009. Integrated water resource management and pollution sources in Cameron Highlands, Pahang, Malaysia. Am. Eurasian J. Agric. Environ. Sci., 5: 725-732.

Jakob, M. and P. Jordan, 2001. Design flood estimates in mountain streams-the need for a geomorphic approach. Can. J. Civil Eng., 28: 425-439.

James, D., 1968. The cultural ecology of a Chinese Villange: Cameron highlands, Malaysia. Chicago Am. Anthropologist, 72: 656-658.

Jessica, L.W., C.S. Michael and D.P. Jonathan, 2005. Quantifying downstream impacts of impoundment on flow regime and channel planform, lower Trinity River, Texas. Geomorphology, 69: 1-13.

Krishnayya, A.B.J.G., 2003. Use of Geographic Information System (GIS) tool in watershed hydrology and irrigation water management. GIS Development-Application-Natural Resource Management.

Philip, B.B., C.H. Wayne and E.V. Baxter, 2008. Hydrology and Floodplain Analysis. 4th Edn., Prentice Hall, New Jersey, ISBN: 0-021-51711-651711,pp: 418-444.

Toriman, M.E., H. Juahir, M. Mokhtar, M.B. Gazim, S.M.S. Abdullah and O. Jaafar, 2009a. Predicting for discharge characteristics in Langat river, Malaysia using neural network application model. Res. J. Earth Sci., 1: 15-21.

Toriman, M.E., A.J. Hassan, M.B. Gazim, M. Mokhtar and S.A.S. Mastura et al., 2009b. Integration of 1-d hydrodynamic model and GIS approach in flood management study in Malaysia. Res. J. Earth Sci., 1: 22-27.

Vörösmarty, C.J., M. Meybeck, B. Fekete, K. Sharma, P. Green and J.P.M. Syvitski, 2003. Anthropogenic sediment retention: major global impact from registered river impoundments. Global Planetary Change, 39: 169-190.

William, L.G., 2006. Downstream hydrologic and geomorphic effects of large dams on American rivers. Geomorphology, 79: 336-360. 